\title{
Closing sounds and related complaints after heart valve replacement with St Jude Medical, Duromedics Edwards, Björk-Shiley Monostrut, and Carbomedics prostheses
}

\author{
Anton Moritz, Ullrich Steinseifer, Georg Kobinia, Kurt Neuwirth-Riedl, Heinrich
} Wolters, Helmut Reul, Ernst Wolner

II. Chirurgische

tätsklinik,

University of Vienna,

Vienna, Austria
A Moritz

E Wolner

Helmholtz Institut for Biomedical

Engineering, Aachen,

Germany

U Steinseifer

$\mathrm{H}$ Wolters

H Reul

Department for

Cardiothoracic

Surgery, General

Hospital Klagenfurt,

Klagenfurt, Austria

G Kobinia

I.ENT Clinic,

University of Vienna,

Vienna, Austria

K Neuwirth-Riedl

Correspondence to:

Dr Anton Moritz,

II. Chirurgische

Universitätsklinik,

Spitalgasse 23, 1090 Vienna

Austria

Accepted for publication

12 September 1991 .

\begin{abstract}
Objective-To measure the noise produced and related subjective complaints after implantation of four different mechanical heart valve prostheses and to identify further factors related to the patient and prosthesis that influence noise generation and complaints.

Design-Sound pressure was measured 5 and $10 \mathrm{~cm}$ and $1 \mathrm{~m}$ from the point of maximal impulse on the body surface by a calibrated meter in quiet rooms with either a decibel(A) filter or octave filters. The patients were asked about their complaints and examined
\end{abstract} physically.

Setting-The measurements were conducted in silent rooms of ear, nose, and throat departments. The patients had been operated on either in a university hospital or a community hospital.

Main outcome measures-Sound pressures of frequency bands and sound pressures measured in $\mathrm{dB}(A)$ at various distances. Complaints registerd were: sleep disturbance, disturbance during daytime, "wants a less noisy prosthesis," and "can hear the closing click".

Patients-143 patients after heart valve replacement with St Jude Medical (n = 35), Duromedics Edwards ( $=38$ ), Carbomedics $(n=34)$ and Björk-Shiley Monostrut $(n=36)$ prostheses operated on between 1984 and 1988 were matched for valve position, ring size, and body surface area.

Results-Duromedics Edwards (33.5 (6) $\mathrm{dB}(\mathrm{A})$ ) and Björk-Shiley Monostrut valves (31 (4) $\mathrm{dB}(\mathrm{A})$ ) were significantly louder than St Jude Medical (24 (4) $\mathrm{dB}(\mathrm{A})$ ) and Carbomedics (25 (6) $\mathrm{dB}(\mathrm{A})$ ) prostheses $(p=0.0001)$ (mean (SD)). The louder valves were significantly more often heard by the patients $(p=0.0012)$ and caused more complaints both during sleep $(p=0.024)$ and during the daytime $(p=0.07)$. Patients with these valves were more likely to want a less noisy valve $(p=0.0047)$. Patients with symptoms were younger, had better hearing, and were more likely to be in sinus rhythm. As well as the type of prostheses, the valve diameter and body height also had an effect on sound emission.

Conclusions-The intensity of the closing click of mechanical valve prostheses was significantly different for various designs. Patient complaints were related to the objectively measured sound pressure. Noise production should be considered when a mechanical valve is selected.

Replacement of stenotic or regurgitant heart valves with mechanical prostheses improves physical ability and long-term survival in patients with congenital or acquired heart valve disease. As well as the risk of complications related to the prosthesis and treatment with anticoagulants-such as embolism, bleeding, and infection-the patients can hear the closing click of the occluders that are typically made from pyrolytic carbon. Complaints about this permanent clicking are generally not noted in the clinical follow up reports. Because the rates of thromboembolic episodes (the complication most affected by valve design) are similar for the currently used mechanical valves, noise generation may well be a criterion for valve selection. We studied the sound intensity produced by various types of mechanical valve prostheses and we investigated whether there is a correlation between the sound emitted and patients' complaints related to noise.

\section{Patients and methods}

We studied 143 patients (mean age 57 years (range 26-76)) after valve replacement with $\mathrm{St}$ Jude Medical ( $n=35)$, Duromedics Edwards $(n=38)$, and Carbomedics $(n=34)$ bi-leaflet valve prostheses and Björk-Shiley Monostrut $(n=36)$ tilting disk prostheses. All valves have a satisfactory haemodynamic performance ${ }^{12}$ and a low rate of thromboembolic complications. ${ }^{3-6}$ The Duromedics valve had been withdrawn from the market because of reports of mechanical disintegration of the prosthesis with leaflet escape, ${ }^{7}$ but was reintroduced after 


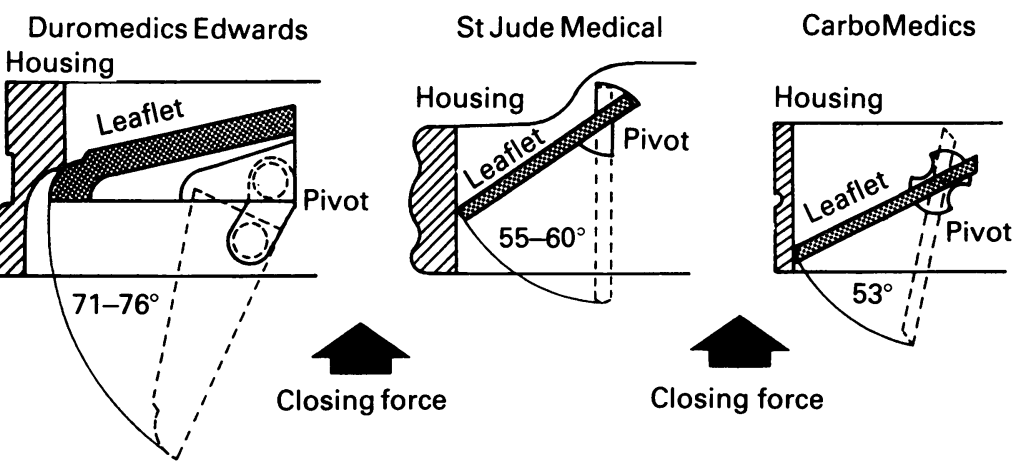

Figure 1 Technical details of the three bi-leaflet valves. The Duromedics Edwards prosthesis has thick, curved leaflets that rotate and move longitudinally in the elongated sockets of the valve housing. The maximal opening angle is $76^{\circ}$. At valve closure the leaflets strike the seating lip of the valve housing. The St Jude Medical valve has a simple pivot articulation and straight leaflets with a maximal opening angle of $85^{\circ}$.The CarboMedics prosthesis also has a simple pivot articulation and its straight leaflets open to $78^{\circ}$ maximally. In the closed position the leaflets of both valves rest against the inner aspect of the valve housing at an acute angle.

changes in production methods, the sewing ring, and component tolerances. Though all the bi-leaflet valves are similar in concept there are considerable design differences between them. The St Jude valve has a simple pivot hinge mechanism and its thin, straight leaflets rest against the housing after a maximal rotation of $55^{\circ}-60^{\circ}$. The leaflets of the Duromedics Edwards valves are curved and move along a combined rotational and longitudinal route in the elongated sockets of the valve housing during valve closure, with a maximal rotation of $71^{\circ}$ to $76^{\circ}$ (fig 1 ). The Carbomedics prostheses again has straight leaflets but a smaller maximal opening angle than the St Jude Medical valve. This design feature leads to an earlier onset of valve closure with less regurgitation. The weight of a single leaflet of a $25 \mathrm{~mm}$ prostheses is highest for the Duromedics Edwards valve (0.388 $\mathrm{g})$ followed by the St Jude Medical leaflet $(0.331 \mathrm{~g})$ and the Carbomedics leaflet $(0 \cdot 28 \mathrm{~g})$. The Shiley Monostrut valve is the most recent version of the Björk prostheses, developed after strut fractures occurred in the convexo-concave valves. At valve closure the occluders of the Björk-Shiley Monostrut and the Duromedics Edwards valves strike a defined structure of

Table 1 Patient characteristics (mean (SD))

\begin{tabular}{|c|c|c|c|c|}
\hline Valve type & $n$ & Annulus diameter (mm) & $B S A\left(m^{2}\right)$ & $\operatorname{Age}(y r)$ \\
\hline \multicolumn{5}{|c|}{ Aortic } \\
\hline $\begin{array}{l}\text { St Jude } \\
\text { Duromedics } \\
\text { Björk-Shiley } \\
\text { Carbomedics }\end{array}$ & $\begin{array}{l}21 \\
24 \\
22 \\
22\end{array}$ & $\begin{array}{l}25 \cdot 1(2 \cdot 3) \\
24 \cdot 4(2 \cdot 2) \\
24 \cdot 3(2 \cdot 2) \\
24 \cdot 4(1 \cdot 6)\end{array}$ & $\begin{array}{l}1.8(0 \cdot 13) \\
1.9(0 \cdot 15) \\
1.9(0 \cdot 2) \\
1.9(0 \cdot 17)\end{array}$ & $\begin{array}{l}53.5(11.9) \\
56.2(10) \\
58.9(11) \\
58.9(11.9)\end{array}$ \\
\hline \multicolumn{5}{|c|}{ Mitral } \\
\hline $\begin{array}{l}\text { St Jude } \\
\text { Duoremedics } \\
\text { Björk-Shiley } \\
\text { Carbomedics }\end{array}$ & $\begin{array}{l}11 \\
11 \\
11 \\
10\end{array}$ & $\begin{array}{l}29(2) \\
27 \cdot 5(0 \cdot 9) \\
29(1 \cdot 5) \\
27 \cdot 6(1 \cdot 6)\end{array}$ & $\begin{array}{l}1.7(0.26) \\
1.8(0 \cdot 15) \\
1.7(0 \cdot 16) \\
1.7(0.22)\end{array}$ & $\begin{array}{l}55(7 \cdot 2) \\
55(13) \\
59 \cdot 9(7 \cdot 5) \\
62 \cdot 9(7)\end{array}$ \\
\hline \multicolumn{5}{|c|}{ Aortic and mitral } \\
\hline $\begin{array}{l}\text { St Jude } \\
\text { Duromedics } \\
\text { Björk-Shiley } \\
\text { Carbomedics }\end{array}$ & $\begin{array}{l}3 \\
3 \\
3 \\
2\end{array}$ & $\begin{array}{l}- \\
- \\
-\end{array}$ & $\begin{array}{l}1 \cdot 6(0 \cdot 1) \\
1 \cdot 7(0 \cdot 15) \\
1 \cdot 8(0 \cdot 1) \\
1 \cdot 7(0 \cdot 3)\end{array}$ & $\begin{array}{l}63(5) \\
56(7) \\
63(6) \\
55\end{array}$ \\
\hline
\end{tabular}

BSA, body surface area. the valve housing, a seating lip in the case of the Duromedics Edwards valve and the two struts in the case of the Björk-Shiley Monostrut valve. In St Jude Medical and Carbomedics prostheses the leaflets rest at an angle of $20-26^{\circ}$ against the smooth inner aspect of the housing.

Patients were matched for valve position, tissue annulus diameter, and body surface area (table 1 ). In the mitral position the valve diameter was smaller for the Duromedics Edwards and Carbomedics valves than for the other groups. Patients completed a questionnaire in which they were asked if they could hear their prosthesis, had their sleep disturbed by the clicking, felt disturbed during the daytime, or would prefer a less noisy prosthesis. The external auditory canal was checked for obstructing foreign bodies. Cardiac rhythm, blood pressure, and the point of maximal impulse of the closing click were determined by physical examination. Sound pressure was recorded with a highly sensitive microphone (Brüel \& Kjäer, type 4145, Denmark) over the previously determined point of maximal impulse at a distance of 5,10 , and $100 \mathrm{~cm}$. Sound pressure was measured by a precision sound level meter (Brüel \& Kjäer 2204, Denmark) in impulse mode to avoid mean measurements and to ensure the display of peak values. To determine sound pressures according to the frequency dependent hearing level of the human ear we used type A filters, which attenuate low and high frequencies, and recorded measured pressures in decibel(A) $(\mathrm{db}(\mathrm{A}))$. The sensitivity for the frequency bands is standardised in IEC 179. The sound level meter was calibrated with a sound level calibrator (Brüel \& Kjäer 4230, Denmark). We also used octave filters to measure sound pressure levels (db SPL) for the frequencies 125,250 , and $500 \mathrm{~Hz}$ and $1,2,4,8$, and $16 \mathrm{kHz}$. All recordings were done in quiet rooms used for audiometry. The hearing threshold was determined in all patients for frequencies ranging from $125 \mathrm{~Hz}$ to $12 \mathrm{kHz}$ for both ears. A Peters audiometer (Sheffield UK) with Telephonics TDH 39 (New York, USA) headphones was used. Patients were asked whether they could still hear the clicking after putting on the headsets. If this was the case broad spectrum noise and band noise was applied through the headsets in increasing intensity to determine the intensity of body conduction.

\section{STATISTICAL ANALYSIS}

Statistical comparisons were made on a personal computer with Statview 512 (Brain Power, Calabasas, California) and JMP software. Variables were tested for normal distribution by the $F$ test and were compared by an unpaired $t$ test or $\chi^{2}$ test. Relations between variables and measured sound pressure were determined by stepwise regression analysis. Further impact of patient and valve related variables on complaints was evaluated by simple and multiple logistic regression analysis.

To compare the hearing threshold and 
Figure 2 Comparison of sound pressures measured at different distances. At 5 and $10 \mathrm{~cm}$ the Duromedics valve was significantly louder than the other types. At 1 metre the Duromedics Edwards and Björk-Shiley Monostrut valves were louder than the average background noise in a quiet room ( 30 $d B(A))$ and the two other valve types. Sound pressures measured at this distance closely resemble those measured next to the patients ear. SJM, St Jude Medical; $D E$, Duromedics Edwards; BSM, Björk-Shiley Monosrut; CM, CarboMedics.

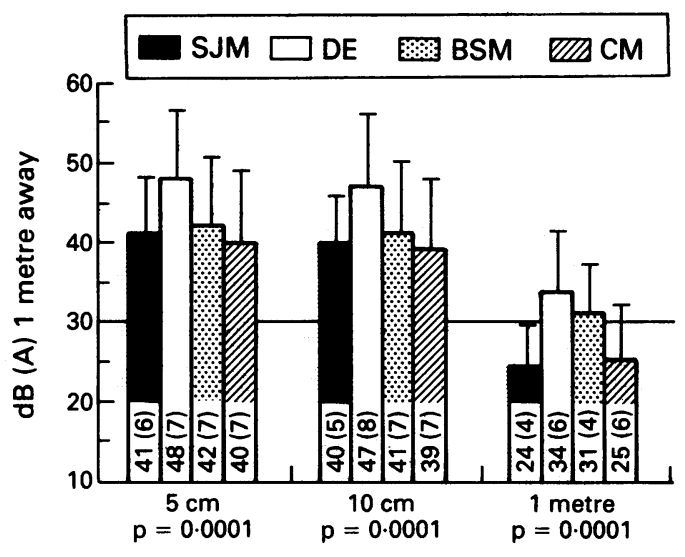

sound pressure we expressed the hearing threshold in db (SPL) by adding the correction values according to ISO 226 to the respective frequency dependent threshold measured at audiometry.

\section{Results}

The sound pressure developed by the prostheses were significantly different at 5,10 , and $100 \mathrm{~cm}$. Five and $10 \mathrm{~cm}$ away from the body surface the Duromedics Edwards prostheses were louder than the other valves. At $1 \mathrm{~m}$ the Björk-Shiley Monostrut and the Duromedics Edwards valves were significantly louder than the two other valve types and their sound pressure levels were higher than the average level of background noise in a silent room (fig 2). The distance of $1 \mathrm{~m}$ seems to be most relevant because the sound pressures measured there are similar to those next to the patient's ear.

Sound pressure for valves in the aortic and mitral positions were similar for all the valve types. After double valve replacement sound pressures were higher than for single valve replacement for all valve types (fig 3 ). Neither systolic or diastolic blood pressure nor blood pressure amplitude correlated with the measured sound pressure for aortic and mitral prostheses.

The differences in noise generation led to significant differences in sound related complaints. Patients with noisier valves were more likely to have symptoms (table 2) and measured sound pressures were significantly louder in patients with symptoms than in those without (fig 4). The sound pressure levels of the frequency bands were not distributed evenly within the audible range. Low and high frequencies dominated. Differences between

Table 2 Noise related complaints

\begin{tabular}{llclr}
\hline Valve type & Valve audible & $\begin{array}{l}\text { Sleep } \\
\text { disturbance }\end{array}$ & $\begin{array}{l}\text { Daytime } \\
\text { complaints }\end{array}$ & $\begin{array}{l}\text { Prefers less } \\
\text { noisy valve }\end{array}$ \\
\hline SJM & $22 / 35(63 \%)$ & $3 / 35(8.6 \%)$ & $0 / 35(0 \%)$ & $4 / 35(11 \%)$ \\
DE & $26 / 38(68 \%)$ & $10 / 38(26 \%)$ & $4 / 38(10.5 \%)$ & $12 / 38(32 \%)$ \\
BSM & $30 / 36(83 \%)$ & $13 / 36(36 \%)$ & $5 / 36(14 \%)$ & $15 / 36(42 \%)$ \\
CM & $13 / 34(38 \%)$ & $5 / 34(15 \%)$ & $1 / 34(3 \%)$ & $4 / 34(12 \%)$ \\
$\chi^{2}$ & $\mathrm{p}=0.0012$ & $\mathrm{p}=0.024$ & $\mathrm{p}=0.07$ & $\mathrm{p}=0.0047$ \\
\hline
\end{tabular}

The noisier valve types (Duromedics Edwards (DE) and Björk-Shiley Monostrut (BSM)) caused significantly more complaints than did the more silent types (St Jude Medical (SJM) and Carbomedics (CM))

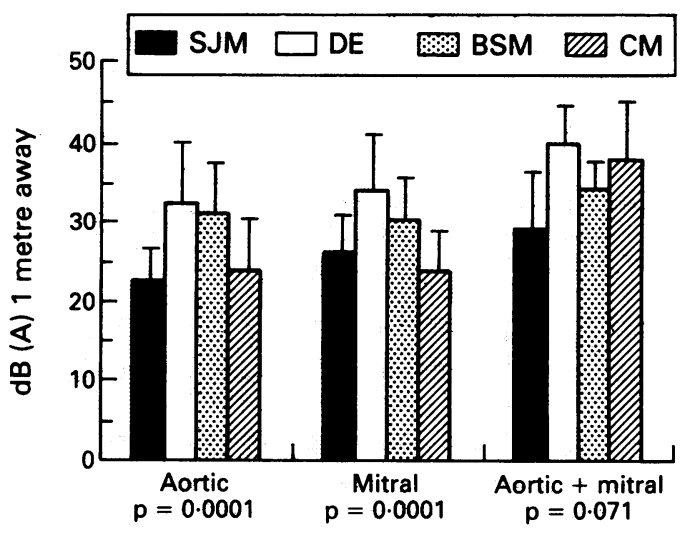

Figure 3 Two implanted prostheses always generated more noise than did one implant. For none of the investigated prostheses was there a significant difference in sound pressures measured at the aortic and mitral positions. See legend to fig 2 for abbreviations.

symptomatic and symptom free patients were most significant at the higher frequencies (table 3). The human hearing threshold attenuates low and high frequencies so that the audible noise levels between low and middle frequency ranges are equalised (fig 5).

Patients with symptoms had better hearing. Again this difference was most significant in the high frequency ranges (table 4). As a result of higher sound pressures and better hearing the audible noise level was significantly higher for patients with symptoms (fig 6).

To identify factors related to the patient and prostheses that influence the noise developed we entered valve diameter, height, body weight, body surface area, body mass index, rhythm, systolic and diastolic blood pressure into a stepwise regression model. Valve diameter and body height emerged as significant variables. As the size of the prosthesis increased so did the energy released at valve closure and hence the sound pressure levels measured $1 \mathrm{~m}$ from the body surface correlated with the tissue annulus diameter of the implanted valve. Body height was an independent variable for developed noise. Body surface area, body weight, or body mass index as an indicator of obesity did not influence developed sound pressure levels nor did blood pressure.

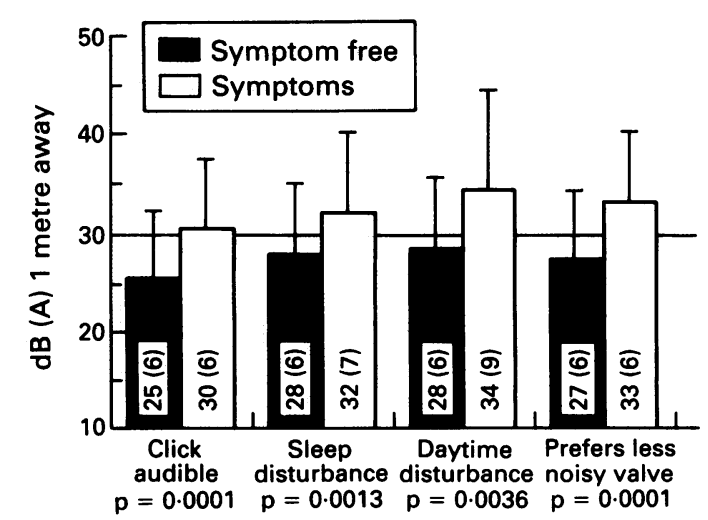

Figure 4 Patients with symptoms had significantly noisier valves. This was true for all four types of complaints. 
Table 3 Frequency dependent sound pressure levels (dB (SPL)) (mean (SD))

\begin{tabular}{lllllll}
\hline Symptom & $125 \mathrm{~Hz}$ & $500 \mathrm{~Hz}$ & $1 \mathrm{kHz}$ & $4 \mathrm{kHz}$ & $8 \mathrm{kHz}$ & $16 \mathrm{kHz}$ \\
\hline $\begin{array}{l}\text { Valve audible: } \\
\quad \text { No }\end{array}$ & $24(7)$ & $14(4)$ & $10(5)^{\star}$ & $11(6)^{\star}$ & $20(8)^{\star}$ & $30(8)^{\star \star}$ \\
$\quad$ Yes & $25(5)$ & $15(3)$ & $12(3)$ & $13(4)$ & $24(7)$ & $34(7)$ \\
Sleep disturbance: & & & & & & \\
$\quad$ No & $25(5)$ & $15(4)$ & $11(4)$ & $12(5)$ & $22(8)^{\star}$ & $31(7)^{\star \star}$ \\
$\quad$ Yes & $26(4)$ & $15(3)$ & $11(2)$ & $13(5)$ & $25(7)$ & $36(7)$ \\
$\begin{array}{l}\text { Daytime disturbance: } \\
\quad \text { No }\end{array}$ & $25(5)^{\star}$ & $15(4)$ & $11(4)$ & $12(5)^{\star}$ & $22(8)^{\star}$ & $32(7)^{\star}$ \\
$\quad$ Yes & $28(4)$ & $15(3)$ & $13(2)$ & $15(4)$ & $28(8)$ & $38(8)^{\star}$ \\
$\begin{array}{l}\text { Prefers less noisy valve: } \\
\quad \text { No }\end{array}$ & $25(6)$ & $14(5)$ & $10(4)^{\star}$ & $12(5)$ & $21(8)^{\star \star}$ & $31(7)^{\star \star}$ \\
$\quad$ Yes & $26(5)$ & $15(3)$ & $12(3)$ & $13(5)$ & $26(7)$ & $37(7)$ \\
\hline
\end{tabular}

${ }^{\star} \mathrm{p}<0.05 ;{ }^{\star \star} \mathrm{p}<0.01$.

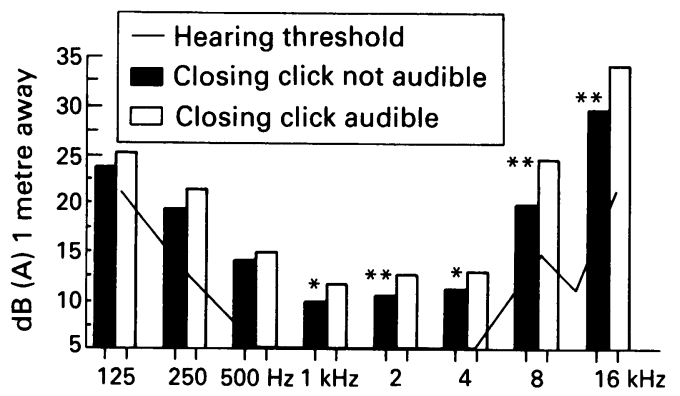

Figure 5 Sound pressure generated by the closing click was higher in the low and high frequency ranges of the audible range, but the effective intensity was attenuated by human hearing characteristics. The high freqency bands of the closing click were perceived most intensely and symptomatic valves produced significantly more noise in these ranges than did asymptomatic ones.

This correlation is true for all patients and for the subgroup after aortic valve replacement (table 5). None of the variables affected the level of developed noise when valves were in the mitral position. A univariate logistic regression analysis showed that sound pressure level $(\mathrm{dB}(\mathrm{A}))$, intensity of 8 and $16 \mathrm{kHz}$ frequency sounds, valve type, heart rhythm, hearing level at 8 and $12 \mathrm{kHz}$, and patient age significantly influenced the occurrence of symptoms (table 6). Sleep disturbances and the request for a less noisy valve were more frequent in patients with intense low frequency body conduction indicated by the level of band noise necessary to override the perception of valve noise. Diastolic blood pressure influenced the audibility of valves only: valve position, body height, body weight, body surface area, and body mass index had no influence on complaints.

All multiple logistic regression models had a value of $R^{2}$ of less than 0.29 and thus could not be used to predict the occurrence of symptoms in an individual patient.

\section{Discussion}

Though implanted mechanical valve prostheses produce a clicking closing sound that often is audible some distance away from the patient, the relation of this noise level to complaints has rarely been evaluated. For modern prostheses the rates of complications are similar. ${ }^{3-58}$ So the effect of noise production on the quality of life of the valve carriers should be considered. Our study proved that there is a significant difference in sound emission between the tested prostheses. Differences were more

Table 4 Hearing thresholds $(\mathrm{dB}(H L))$ in symptomatic and asymptomatic patients (mean $(S D))$

\begin{tabular}{|c|c|c|c|c|c|c|}
\hline Symptom & $125 \mathrm{~Hz}$ & $500 \mathrm{~Hz}$ & $1 \mathrm{kHz}$ & $4 \mathrm{kHz}$ & $8 \mathrm{kHz}$ & $16 \mathrm{kHz}$ \\
\hline $\begin{array}{l}\text { Valve audible: } \\
\text { No } \\
\text { Yes }\end{array}$ & $\begin{array}{l}17(6) \\
17(8)\end{array}$ & $\begin{array}{l}15(9) \\
12(8)\end{array}$ & $\begin{array}{l}17(11)^{\star} \\
13(10)^{*}\end{array}$ & $\begin{array}{l}41(22)^{\star} \\
28(19)\end{array}$ & $\begin{array}{l}49(23)^{\star} \\
33(23)\end{array}$ & $\begin{array}{l}67(27)^{\star} \\
54(28)\end{array}$ \\
\hline $\begin{array}{l}\text { Sleep disturbance: } \\
\text { No } \\
\text { Yes }\end{array}$ & $\begin{array}{l}17(8) \\
18(7)\end{array}$ & $\begin{array}{l}13(9) \\
11(7)\end{array}$ & $\begin{array}{l}15(11) \\
11(8)\end{array}$ & $\begin{array}{l}34(21)^{\star} \\
24(18)\end{array}$ & $\begin{array}{l}41(24)^{\star} \\
30(24)\end{array}$ & $\begin{array}{l}60(28)^{\star} \\
49(28)\end{array}$ \\
\hline $\begin{array}{l}\text { Daytime disturbance: } \\
\text { No } \\
\text { Yes }\end{array}$ & $\begin{array}{l}17(8) \\
18(8)\end{array}$ & $\begin{array}{r}13(9) \\
9(7)\end{array}$ & $\begin{array}{c}15(11) \\
9(7)\end{array}$ & $\begin{array}{l}33(21) \\
24(18)\end{array}$ & $\begin{array}{l}39(24)^{\star} \\
22(18)\end{array}$ & $\begin{array}{l}59(28)^{\star \star} \\
38(22)\end{array}$ \\
\hline $\begin{array}{l}\text { Prefers less noisy valve } \\
\text { No } \\
\text { Yes }\end{array}$ & $\begin{array}{l}17(8) \\
17(7)\end{array}$ & $\begin{array}{l}14(9)^{\star} \\
10(6)\end{array}$ & $\begin{array}{l}15(11)^{\star} \\
10(7)\end{array}$ & $\begin{array}{l}35(21)^{\star \star} \\
24(19)\end{array}$ & $\begin{array}{l}43(24)^{\star \star} \\
25(20)\end{array}$ & $\begin{array}{l}65(27)^{\star \star} \\
42(25)\end{array}$ \\
\hline
\end{tabular}

${ }^{\star} \mathrm{p}<0.05 ;{ }^{\star \star} \mathrm{p}<0.01$. consistent than in vitro results, which were obscured by the noise created by the valve tester. ${ }^{9}$

Noisy valve types clearly caused more complaints, but other variables related to the prostheses and patient also influenced noise production and the rate of complaints. Young patients had hearing in the high frequency range of the closing click (15 to $16 \mathrm{kHz}$ ) and thus they perceived the valve noise more intensely than older patients. Patients in sinus rhythm had more complaints than did those in atrial fibrillation, though there was no sigificant difference in irregular heart beats. In the logistic regression young age was a much stronger predictor of complaints than sinus rhythm and the higher rate of compaints may thus have been caused by the younger age of patients in sinus rhythm.

The bigger the prosthesis and the greater the occluder mass the higher the energy release at valve closure. The sound pressure increased with annulus diameter. Blood pressure did not influence measured sound pressure nor the rate of complaints, despite its likely influence on the
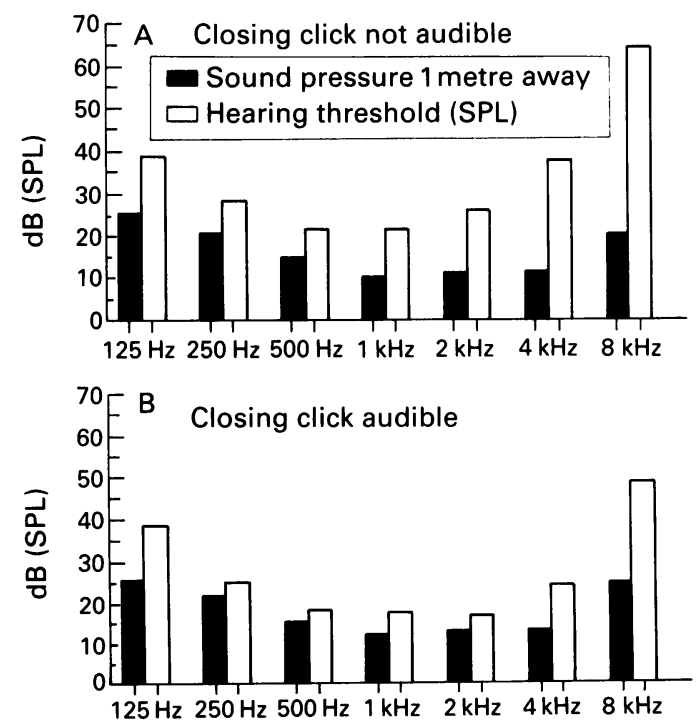

Figure 6 Patients who can hear their valve had louder valves and had better hearing than those who did not. As a result the difference between sound pressure and hearing was significantly greater for the asymptomatic patients $(A)$ than for those with symptoms $(B)$. measured sound pressure between regular and 
Table 5 Variables related to the prosthesis and patient that influenced valve noise determined by stepwise regression analysis of valve diameter and body height on developed sound pressure levels

\begin{tabular}{lllll}
\hline & Coefficient & $S E$ & Probability & Partial F \\
\hline All patients: & & & & \\
$\quad$ Valve size & 0.5 & 0.197 & 0.01 & 6.83 \\
Height & 0.138 & 0.054 & 0.012 & 6.46 \\
& & & & \\
Aortic implants: & 0.18 & 0.085 & 0.038 & 4.43 \\
$\quad$ Valve size & 0.74 & 0.33 & 0.028 & 5.03 \\
Height & & & & \\
\hline
\end{tabular}

energy at valve closure. Also in preliminary in vitro studies the relation between blood pressure and, sound emission was weak (Wolters $\mathrm{H}$, Theses RWTH Aachen). Not all the variables with an impact on sound generation also influenced the rate of complaints and vice versa.

The closing sound of a mechanical valve prosthesis consists of low frequency oscillations generated by the blood column and tissue structures within the chest and of the high frequency click caused by the vibrations of the occluder. ${ }^{10}$ For leaflets made from pyrolytic carbon these high frequencies range between 8 and $16 \mathrm{kHz} .{ }^{11}{ }^{12}$ Sound propagation within the chest is rather complex, because moving blood, air in the lungs, and solid tissues and bones will conduct and reflect sound differently. ${ }^{13}$ Because many patients were able to hear their valve when they were wearing headsets, some of the sound must be conducted by the body.

Externally measurable noise increased with body size, but height did not influence the rate of complaints. In obese individuals subcutaneous and interstitial fatty tissue did not dampen sound emisson or reduce complaints. Patients who heard their valve by body conduction had significantly more sleep disturbance. Internally conducted low frequency noise, in the 125 to $250 \mathrm{~Hz}$ range, influenced the rate of sleep diturbance and the desire for a less noisy valve.

Greater noise generation may also be related to component wear. The Duromedics Edwards valve was withdrawn from the market after reports about leaflet escape and fractures ${ }^{7}$ and the Shiley Monostrut valve is a reinforced version of the $70^{\circ}$ convexo-concave Björk valve in which strut fractures and disk embolisations have been reported. ${ }^{14}$ Both prostheses were identified as "noisy" valves in our study. Closing energy, calculated from circumferential velocity and leaflet weight, is slightly higher for the St Jude Medical than for the Duromedics Edwards valve. ${ }^{15}$ Early valve closure, a smaller travel angle, and lighter leaflets reduce the closing energy of the Carbomedics valve. The monodisc of the BjörkShiley Monostrut valve strikes the metal strut at the highest circumferential velocity. ${ }^{15}$ Small design details seem to cause the differences in noise generation between the three types of bileaflet valves. Compliance of the sewing ring and design of the seating lip are probably more important than the closing energy. This accords with the findings of cavitation bubble formation caused by fluid deceleration at the instant of closure. Increasing the sewing ring compliance and modifications of the seating lip significantly reduced the shock load at valve closure. ${ }^{1617}$

The noise generated by mechanical valve prostheses causes significant complaints in patients after heart valve replacement. The four modern prostheses that we tested had a similar rate of valve related complications but two noisier types were identified. Because measured sound intensity correlated with the rate of noise-related complaints the generation of sound should be considered when a mechanical valve is selected.

1 Richard GJ, O'Bannon W, More RB. An in vitro comparison of $29 \mathrm{~mm}$ mitral Carbomedics and St Jude Medical artificial heart valves. In: Bodnar E, ed. Surgery for heart valve disease. London: ICR Publishers, 1990:628-33.

2 Knott E, Reul H, Knoch M. In-vitro comparison of aortic heart valves prostheses. Part 1: Mechanical valves. $J$ Thorac Cardiovasc Surg 1988;96:128-33.

3 Thulin LI, Bain WH, Huysmans EH, et al. Heart valve replacement with the Björk-Shiley Monostrut valve: early results of a multicenter clinical investigation. Ann Thorac Surg 1988;45:164-70.

Table 6 Results of univariate logistic regression analysis of the impact on the occurrence of sound related complaints of various variables related to the patient or prostheses

\begin{tabular}{|c|c|c|c|c|}
\hline \multirow[b]{2}{*}{ Variable } & \multicolumn{4}{|l|}{ All positions } \\
\hline & Valve audible & Sleep disturbance & Daytime complaints & Prefers less noisy valve \\
\hline Systolic blood pressure & 0.44 & $0 \cdot 12$ & $0 \cdot 2$ & $0 \cdot 7$ \\
\hline Diastolic blood pressure & 0.014 & $0 \cdot 197$ & 0.49 & $0 \cdot 21$ \\
\hline Blood pressure amplitude & 0.026 & 0.37 & 0.41 & 0.78 \\
\hline Body height & $0 \cdot 7$ & $0 \cdot 21$ & $0 \cdot 3$ & 0.44 \\
\hline Body weight & 0.6 & 0.97 & $0 \cdot 78$ & $0 \cdot 66$ \\
\hline Body surface area & 1 & 1 & 1 & 1 \\
\hline Body mass index & 0.4 & 0.064 & 0.82 & 0.64 \\
\hline Sinus rhythm/atrial fibrillation & 0.011 & 0.039 & 0.034 & 0.0006 \\
\hline Body conduction & - & 0.026 & $0 \cdot 122$ & $0 \cdot 1$ \\
\hline Sound pressure at $10 \mathrm{~cm}$ & 0.00032 & 0.01 & 0.34 & 0.0011 \\
\hline Sound pressure at $1 \mathrm{~m}$ & 0.000003 & 0.0016 & 0.0048 & 0.000004 \\
\hline Sound pressure $125 \mathrm{~Hz}(1 \mathrm{~m})$ & 0.57 & 0.072 & 0.025 & 0.088 \\
\hline Sound pressure $8 \mathrm{kHz}(1 \mathrm{~m})$ & 0.00034 & 0.055 & 0.029 & 0.0012 \\
\hline Sound pressure $16 \mathrm{kHz}(1 \mathrm{~m})$ & 0.00022 & 0.0019 & 0.021 & 0.000041 \\
\hline Hearing level $125 \mathrm{~Hz}$ & 0.98 & 0.49 & $0 \cdot 8$ & 0.89 \\
\hline Hearing level $8 \mathrm{kHz}$ & 0.00043 & 0.025 & 0.012 & 0.00019 \\
\hline Hearing level $12 \mathrm{kHz}$ & 0.00232 & 0.057 & 0.017 & 0.00011 \\
\hline Age & 0.000024 & 0.019 & 0.014 & 0.00015 \\
\hline Band noise $125 \mathrm{~Hz}$ & 0.75 & 0.00059 & $0 \cdot 13$ & 0.042 \\
\hline Band noise $250 \mathrm{~Hz}$ & 0.51 & 0.00161 & 0.13 & 0.027 \\
\hline Valve position & 0.4 & 0.47 & $0 \cdot 19$ & $0 \cdot 21$ \\
\hline Valve diameter & 0.075 & 0.47 & $0 \cdot 22$ & 0.55 \\
\hline Valve type & 0.0012 & 0.024 & 0.077 & 0.0047 \\
\hline $\mathrm{DE}+\mathrm{BSM} / \mathrm{SJM}+\mathrm{CM}$ & 0.0019 & 0.0047 & 0.012 & 0.0005 \\
\hline
\end{tabular}


4 Arom KV, Nicoloff DM, Kersten TE, Northrup III WF, Lindsay WG, Emery RW. Ten years' experience with the St Jude Medical valve prostheses. Ann Thorac Surg 1989;47:831-7

5 Geiran O, Froysaker T, Ihlen H, Simonsen S, Vatne K. Carbomedics: a new bileaflet heart valve. In: Bodnar E, ed. Surgery for heart valve disease. London: ICR Publishers, Surgery for
1990:551-7.

6 Klepetko W, Mortiz A, Kühnl-Brady G, et al. Implantation of the Duromedics bileaflet cardiac valve prosthesis in 400 patients. Ann Thorac Surg 1987;54:14-26.

patients. Ann Thorac Surg 1987;54:14-26.
7 Klepetko W, Moritz A. Leaflet fracture in DuromedicsEdwards bileaflet valves. J Thorac Cardiovasc Surg 1989;97:90-4.

8 Moritz A, Klepetko W, Khünl-Brady G, et al. Four year follow up of the Duromedics Edwards bileaflet valve prostheses. J Cardiovasc Surg (Torino) 1990;31:274-82.

9 Thulin LI, Reul H, Giersiepen M, Olin CL. An in vitro study of prosthetic heart valve sound. Scand $J$ Thorac Cardiovasc Surg 1989;23:33-7.

10 Köymen H, Altay BK, Ider YZ. A study of prosthetic heart valve sounds. IEEE Trans Biomed Eng 1987;34:853-63.

11 Gordon RF, Najmi M, Kingsley B, Segal BL, Linhart LW.
Spectroanalytic evaluation of aortic prosthetic valves Chest 1974;66:44-9.

12 Schöndube F, Keusen H, Messmer BJ. Physical analysis of the Björk Shiley prosthetic valve sound. J Thorac Cardiovasc Surg 1983;86:136-41.

13 Meno F, Reddy PS, Bernardi L. Heart sound propagation in the human thorax. Clin Phys Physiol Meas 1985;6:123-9.

14 Lindblom D, Rodriguez L Bjork VO. Mechanical failure of the Björk-Shiley valve. J Thorac Cardiovasc Surg 1989; 97:95-7.

15 Knoch M, Reul H, Rau G. Flow characteristics of six mechanical heart valve prostheses in aortic position: design related model studies In: Bodnar E, ed. Surgery for heart valve disease. London: ICR Publishers, 1990: 590-601.

16 Kafesjian $R$, Wieting $D$, Stobie $R$. Heart valve sewing ring compliance: The effect on closing impact forces and cavitation bubbles [abstract]. Int J Artif Organs 1990; 13:607.

17 Wieting DW, Kafesjian R, Stobie R, Adlparvar P, Ward D, Unger J. Hi-speed videography of Edwards-Duromedics heart valve dynamics and fluid dynamics [abstract]. Int $J$ Artif Organs 1990;13:608. 